QIJIS: Qudus International Journal of Islamic Studies

Volume 6, Issue 1, February 2018

\title{
THE EXISTENCE OF KUDUS ISLAMIC LOCAL CULTURE TO PREVENT RADICALISM IN GLOBALIZATION ERA
}

\author{
Suciati and Azizah Maulina Erzad \\ STAIN Kudus, Central Java, Indonesia \\ suci@stainkudus.ac.id \\ azizahmaulina@stainkudus.ac.id
}

\begin{abstract}
Many acts of terror happen recently. The spread of radicalism and terrorism is well-supported by the sophisticated media and technology. In addition, this advanced information technology is also slowly eroding the local cultures. This paper focuses on how to prevent radicalism by maintaining the local culture in Kudus regency. The method of this research is a qualitative method that uses literature study by examining some of the literatures both printed and online. The results of this study show that Kudus regency is still very strong with their local wisdom. This is shown by the Islamic local cultures which are still preserved today, those are: Dandangan, Kupatan dan Syawalan, Bulusan, Kudus Mosque Minaret, Buka Luwur and Cow as Sacred Animal. Globalization tries to erode those local cultures. Nevertheless, Sunan Kudus teaching brings local wisdom of Kudus society could prevent the radicalism in this globalization era.
\end{abstract}

Keywords: Kudus, Islamic local culture, radicalism 


\section{A. Introduction}

In globalization era, the development of information technology causes the wide spread of information about radicalism and terrorism. Unfortunately, the lack of people's ability in receiving, processing, and filtering the information makes the situation getting worse. So whatever they see, read, and hear in the media will be considered as a real truth.

This condition is well understood by the radical groups. They use the media to convey the radical messages to urge people to believe that their actions are correct and should be supported. The main target of the spread of radical-terrorist concept in the media is the younger generation because they actively follow the news in the media (especially online media). Besides that, children>s young age also still firmly in the establishment; was busy looking for identity, so they are easily influenced. Radicalism and terrorism prevention efforts in the community, especially young people, require a different method, namely the Cultural Approach or the local culture.

The cultural approach is closely related to Islam and local culture. Islam as a universal religion is a mercy to the worlds, and the presence on earth. Islam is mingled with the local culture, that between Islam and local culture in a society cannot be separated, but both are mutually supportive.

Culture touches all aspects and dimensions of perspective, attitude to life and the actualization of human life in this nation (Asnawan, 2011: 85). We should follow the methodology of Sunan Kalijaga in spreading Islam in Java. When he saw the collapse of Majapahit feudalism, he encourages the acceleration of the transformation process, instead using local elements to sustain the effectiveness of the technical and operational aspects.

In the Javanese society there are many relics of the HinduBuddhist tradition that has been inserted teachings of Islam. The pattern of the spread of Islam and Islamic society development conducted by Walisongo in Indonesia, especially in Java, is largely 
determined by his intelligence in using the cultural approach. They offers an adaptive Islamic culture and appreciate the local culture. An acculturative cultural strategy as was done by Walisongo still needs to be developed in Indonesia, although Muslims in Indonesia now has become the majority.

The local culture is very important to be maintained especially in this globalization era. It gives an identity to the society where the culture exists and develops. It is a cultural heritage from our ancestors that should be well-kept and maintained. Furthermore, the local culture has a function as a means to filter the western cultures which try to enter our country in a huge wave and most of them doesn't appropriate with eastern culture values. In this sophisticated era, everything is computer-based. It tends to make people forget and leave their cultures then easily trust, receive, and follow whatever information they get including the radicalism concept. The cultural approach is believed to be an alternative to prevent and stem radicalism and terrorism because it touches directly to the root of the problem, which is related to local issues, such as; policy, alienation, and poverty.

This study discusses some problems. First, it elaborates about kinds of local cultures which exists in the society. In this point, the researchers only focus on the existence of local cultures in Kudus regency. Second, it discusses the correlation between globalization and Kudus local cultures. And the last, it analyzes the existence of Kudus Islamic local culture to prevent the radicalism in globalization era.

In this research, the writers used library research method. The purpose was getting the complete data, whether they are in online or printed sources. There were four steps done by the writers. They were preparing the equipment for making some notes, arranging the job list, managing research time, reading and making research note. 


\section{B. Discussion}

\section{Culture}

Culture is a complex concept, and no single definition that is agreed in the literature. So, there are so many and various possible definitions examined. This definition guides this study: culture is a set of shared and enduring meaning, values, and beliefs that characterize national, ethnic, or other groups and orient their behaviour (Mulholland: 1991).

Cultural differences have big manifestation in different level and depth. Hofstede (1997) categories that symbols as the most superficial and values as the deepest manifestations of culture. Meanwhile, there are heroes and rituals between both of them.

a. Symbols are words, gestures, pictures, or objects which have a particular meaning and it will be recognized by sharing particular culture. New symbols develop easily and the old ones disappear. Symbols from certain group can be copied or imitated by the others. This is the reason why symbols are considered as the outermost layer of a culture.

b. Heroes are persons, past or present, real or fictitious, whose characteristics that are highly respected in a culture. They also serve as models for behavior.

c. Rituals are collective activities, sometimes useless in reaching desired purpose, but they are considered as important thing socially. Nevertheless, they are done for their own sake (for example: paying respect to others, ways of greetings, religious and social ceremonies)

d. The main culture is formed by values. They are used as tendencies to have relations with the others (good-bad, 
right-wrong, natural- not natural). Many values make people who hold them unconscious. For that reason, they often cannot be discussed and observed by the other people. Values can only be understood and concluded from the way how people act in different circumstances.

e. Symbols, heroes, and rituals are the real or visual aspects of culture implementation. The true cultural meaning of the practices is intangible; this is proved only when the practice interpretation is done by the insiders.

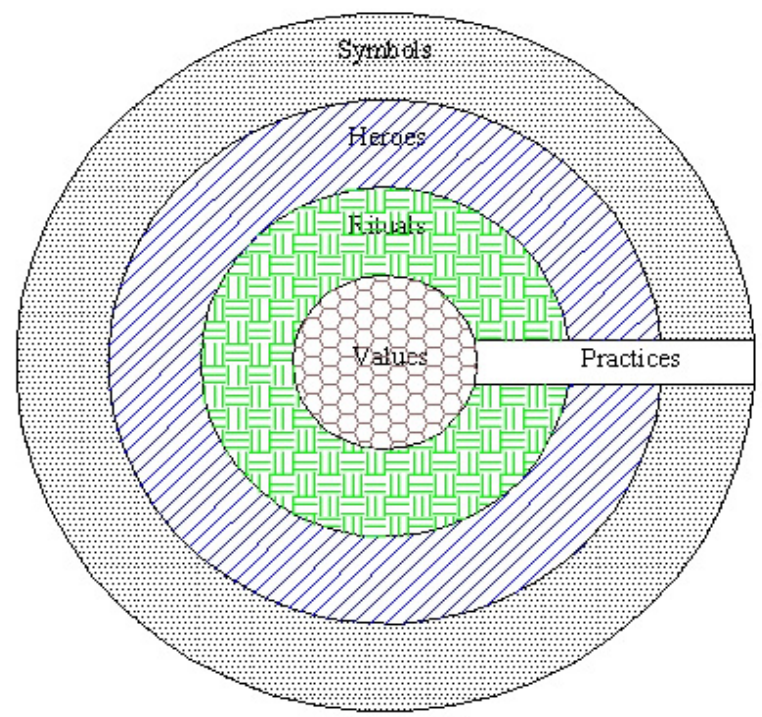

Figure 1. Manifestation of Culture at Different Levels of Depth

People even within the same culture carry several layers of mental programming within themselves. Different layers of culture can be described into these levels:

a. The national level. It is related to the nation as a whole.

b. The regional level. It is related to ethnic, linguistic, or religious differences in a nation.

c. The gender level. It is related to gender differences 
(female and male)

d. Thegeneration level. It is related to the differences between grandparents and parents, parents and children.

e. The social class level. It is related to educational opportunities and differences in occupation.

f. The corporate level. It is related to the specific culture of an organization which is applicable to the employee.

All of those layers can be shown in Figure 2 below.

\section{Layers of Culture}

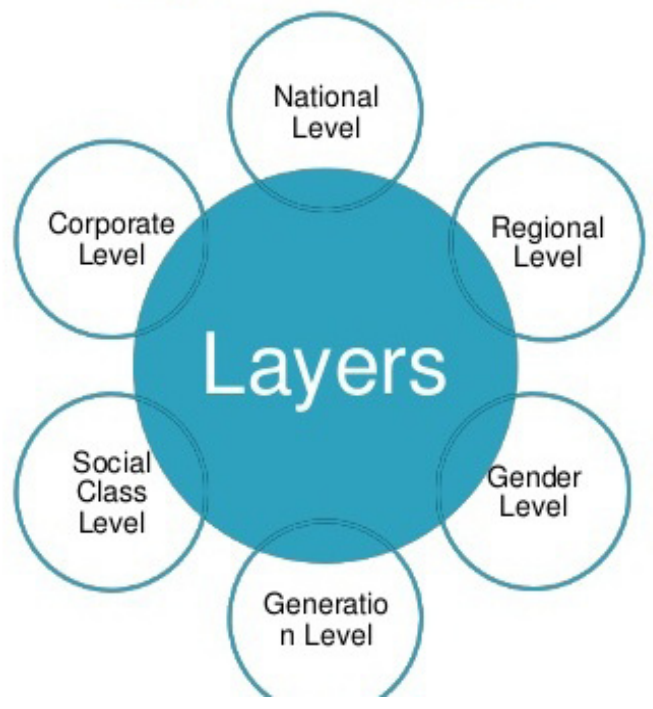

Figure 2. Layers of Culture

\section{Local Culture/Local Wisdom}

. In the discipline anthropology, it knowns a term of local genius which was first introduced by Quaritsh Wales. Anthropologists have discussed at length this sense of local genius. Local genius is also cultural identity, identity/personality national culture that causes it is able to absorb and review the foreign culture based on their own characters and abilities. 
It can be concluded that local culture is the implementation of ancestors' tradition. It can also be defined as a good culture value which exists in the society. It means to know the meaning of local culture in a certain society, we should understand the good cultural values containing in the society itself. The most important thing from local culture is it contains natural values which should be implemented as a tradition and receivable to the society, for example in architecture aspect. The traditional values have a function to harmonize the human life by way of respect, maintain and preserve the natural environment.

\section{Globalization}

Dulupçu and Demirel (2015: 4) state that globalization term covers many concepts. The term cannot be considered solely as political, cultural or economic process. Globalization covers a process that involves the whole dimensions. For that reason, different people can give different meaning for the term of globalization. They can have different interpretation based on time or location, its dimensions, cause or result cycles and its perspectives. Nevertheless, people can differentiate that term according to the disciplines.

\section{Kudus Islamic Local Culture}

Kudus is a regency in Central Java, located $51 \mathrm{Km}$ to the east of Semarang. This regency is surrounded by Pati regency in east, Grobogan regency and Demak regency in south, and Jepara regency in west. Kudus is the smallest regency in Central Java with a total area reaches 42,516 hectares. It has 9 sub-districts.

Nowadays, not just as cigarrette city, Kudus is also well known as 'Kota Santri' or the city of Islamic Students. In this regency, there were two Sunan. They were Sunan Kudus and Sunan Muria. Both of them are also caled Walisanga.

Kudus is also a regency that is rich with its Islamic local cultures. They are dandangan, kupatan, bulusan, buka luwur, etc which are so interesting to be studied and researched. 
a. Dandangan

The cultural approach has an important position so it must also apply to education in schools. Students should be taught from an early age and taught to the resolution of conflicts through customary institutions, or cultivate a game-group that engages people (gasing games, kite or hide and seek). Local values through the game can be a model of teaching in schools are effective in preventing radicalism and terrorism among students. Educators can modify or manipulate the values of the local game has become to be a teaching material in order to strengthen the relationship and silahturahmi between individuals and between groups, so that by itself the potential for conflicts of friction can be reduced or even eliminated altogether.

Dandangan history comes from the sound of the drum is beaten, and signifies the start of Ramadan. By the surrounding community, the tradition of the drum was known as Dandangan. Formerly announcement 1 Ramadan led by Sunan Kudus. He is believed to have astronomy qualified by the Holy society at that time. One of the Wali Songo clerics who lived in the 16th century it was read in the court of the Holy tower. The announcement marked with the beat of the drum.

\section{b. Kupatan and Syawalan}

At every celebration of Eid, whereby Muslims finished fasting during the whole month, we can find the diamond in almost every home to celebrate. Foods made from cooked rice and wrapped in a palm leaf is indeed identical to wordiness. With companion vegetable curry dish, the diamond always decorates the tables on the celebration of Eid.

Kupatan tradition comes from the time of the guardians are also spreading the religion of Islam in Java. If you look he says, comes from the words Kupatan kupat which in Javanese language means «admit lepat» or recant. Actually, this tradition during the first carried out on the 37 th or after fasting the 36th. Kupatan implemented in 
various areas among others in Bulusan Village Hadipolo (Jekulo district), Village Kesambi (Mejobo district), Sendang Jodo Purworejo (Bae district).

Tradition is no longer owned by Muslims and people of Java alone, but belongs to all the people of Indonesia. This tradition is also rich with wisdom and piety that are relevant to the present context. He can be defined as a relationship between people to interact through activities that are not prohibited, plus it contains something good and fun. So, doing halal bihalal, should not solely by forgiving through intermediaries verbal or on greeting cards alone, but must be followed by deeds good and pleasant for others especially those who are invited to do halal bihalal. Syawalan also glue the unity and integrity, and encourage people to be honest.

By eating the diamond symbolized the fourth has been able to conquer lust, namely anger, the emotional desire; aluamah or desire to satisfy hunger; supiah is the desire to have something beautiful and mutmainah, desire to force people. Syawalan tradition conducted by Prince Sambernyawa is now preserved by the Islamic organizations, and government agencies and the private sector in terms of halal bi halal. Interestingly, participants of religious gatherings are not only Muslims, but all citizens of various faiths, ethnicity, race and class.

\section{c. Bulusan}

Bulusan (also called Bulusan Tradition) is one of the traditional warning the Islamic community in Kudus, Central Java, Indonesia, which held seven days after Eid. The celebration of this tradition centered in Hamlet Source, Hadipolo Village, District Jekulo, Kudus. This tradition comes from a legend related to Sunan Muria. He told rebuked local residents who still work in the fields at night during Ramadan precisely on the eve of Revelation of the Qur>an so that residents turn out to be fleeced.

Sunan Muria stuck his stick into the ground, out 
springs or sources. The exit of the water is then it becomes a name of village, namely Dukuh Sumber. Once these places inhabited community, Kyai Dudo then ask every 7 th Shawwal to create a ritual to pray for two of his disciples being fleeced. Ritual prayer followed by the rest of society Hamlet source is then referred to as a tradition Bulusan, be interesting spectacle Kudus society today. Bulusan tradition today not only presents a ritual prayer in petilasan Kyai Dudo, but also no activity-rehearsal rehearsal spring and a variety of other activities, including a parade of music and other stage entertainment.

d. Kudus Mosque Minaret

There is a famous mosque in Kudus namely Menara Kudus Mosque or Al-Aqsha Mosque. The mosque preserves the tomb of Sunan Kudus, one of the nine Islamic saints of Java (the Wali Sanga), and it is a popular pilgrimage destination. This mosque is famous with its architecture that is different from the other mosques.

This mosque is fascinating for another reason. Its minaret looks like the tower of a Hindu temple. The split brick gateways outside the mosque also have a Hindu look. It shows the acculturation between Hindu and Islamic culture because Sunan Kudus respects Hindu's belief at that time. It is one of his strategies to attract and invite people to receive Islam.

e. Buka Luwur

Buka Luwur Ceremony of Sunan Kudus' Tomb is a ritual replacement netting fabric/cloth (luwur) used to wrap headstone, cupola, tombs and buildings around the tomb of Sunan Kudus. This event is a tradition because it is done regularly every year and held down for generations. The tradition of Buka Luwur Ceremony of Sunan Kudus' Tomb in Kudus Regency is held to commemorate the haul of Sunan Kudus. Sunan Kudus date of the death is not known for certain, but the scholars agreed to hold the Buka Luwur ceremony on the 10th of Muharram. This ceremony involves 
more than a thousand people. Most involved are locals from Kauman and surrounding areas. The procession of the ceremony runs for 10 days.

Most people believe that former luwur/cloth of tomb of Sunan Kudus bring blessings and good fortune. They also assumed that the former cloth tomb of Sunan Kudus can be used as a talisman for the person who keeps it. Because it flows prayers, tahlil and Qur'an citation from the pilgrims of Sunan Kudus' tomb.

Wrapped rice (usually called sego jangkrik) which is obtained at the time of ritual Buka Luwur is believed efficacious (Indrahti, 2012: 98-99). The Kudus society believes that they who eat the rice will always be healthy. If the rice is dried and sown in the field/ground, it will give fertility. The rice was dried, pounded until smooth, then mixed with animal feed, will make it quick and healthy cattle breed. It can be seen that the perception of Kudus Regency society respects and enthusiastic for Buka Luwur ceremony.

f. Cow as a sacred animal

When Islam was spread in Indonesia for the beginning, the missionaries used original Indonesian culture to intruduce Qur'an. They combined religion and culture so both of them could be balanced, understood and received by people quickly. To respect Hindi followers who live in Kudus, Sunan Kudus asked Kudus people not to cut cow/bull as cow/bull was a holy animal in Hindu. For culinary in Kudus, there are popular food, namely Soto Kebo (buffalo), not Soto Sapi (cow) and Sate Kebo (Buffalo Satay), not Sate Sapi (Cow Satay). Soto Kebo is called Soto Kudus. In ingredients of Soto Kudus, we can find buffalo meat, not beef. The reason is that in ancient Hindu, the cow is one of sacred animals forbidden to be killed. For that reason, Sunan Kudus did not use beef because of honoring the Hindu's people. 


\section{The Influence of Globalization to Kudus Local Culture}

If the access to culture is unprecedented, more people will have gateway to see, hear, and experience new phenomena that were never accessible before (Smith: 2000). This condition will cause some consequences if there is no unmonitored access. Some of them are misinterpretation, stereotyping and the loss of cultural and intellectual properties. According to him, there are several negative impacts of globalization on culture. Some of them are the change of social values and exploitation of workers and markets. Finally, the commercial media and product can drown the local cultural influences little by little.

Loss of group identity or local culture can be happened when the globalization supports the individualism. It promotes a homogeneous set of values and beliefs. If the people adopt different, wrong and dangerous culture or ideology and it is supported by a media, it will be published and endanger many aspects, especially local culture.

Globalization can create colonization. And, colonzation will have impacts on intellectual property and cultural rights. Global access for information open the big opportunity to get information, especially culture. If there is no filter and free to access everything, cultural signs or icons which are considered as heritage will be lost. Smith (2000) said that the cultural icons are as living heritage and integral identity part. Nevertheless, it is so difficult to monitor and control the globalization, so preventing and prosecuting the local culture should be done appropriately.

On the other side, technology also empowers the culture variety because it gives self-representation and information about everything happened around the world. Global media also promote the awareness and knowledge about certain cultures or identities. It also makes people give comments and be critical on the issue about culture so they can preserve their culture. Moreover, it can also develop their knowledge acquisition about cultural ways. It shows that they keep their cultural diversity. 
Media also control the cultural things. They are like artifacts, symbols and signs that are used or considered as cultural property. If cultures as their public image are controlled by media, people will be easy to manage and represent their images well without any misunderstanding or misinterpretation.

It is so different with Ginsburg (2002: 39-57) who states that mass media help in preserving the nations' cultures. It means that technology can be used for preserving the language, tradition and culture. By the existence of technology, the autonomy and the empowerment can make people have self-interpretation and preserve their personal and collective identity.

Moreover, in bussiness, Hofstede (1997) asks people to determine the extent of global involvement. He says that the bussiness which operate globally need to have the same cultural awareness level. Figure 3 below describes how a company must be aware and understand global cultures in different levels. For doing bussiness in domestic or foreign area, they need to understand the cultural differences so they will have cultural awareness. Such thing is very essential and important.

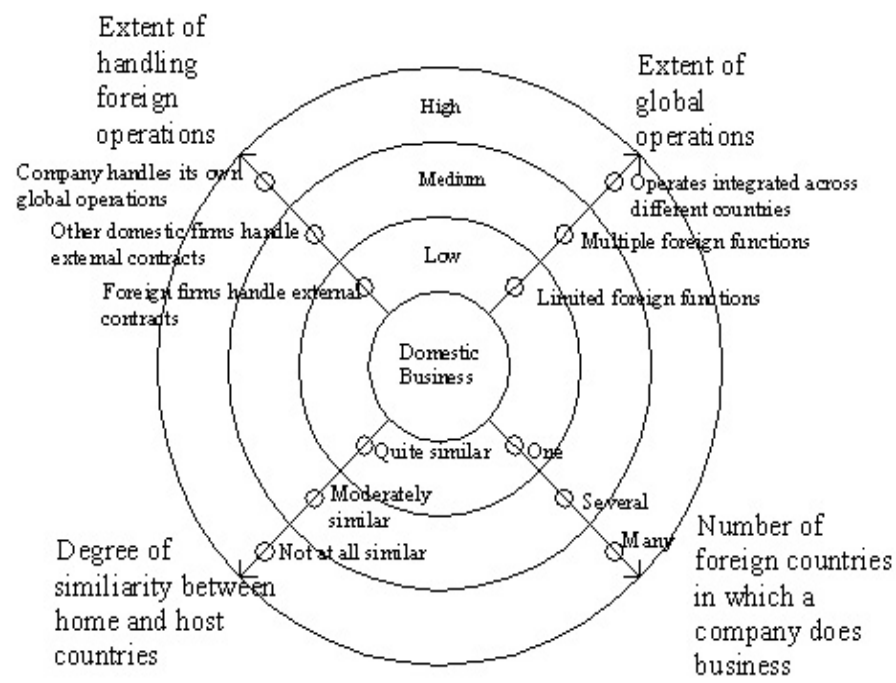

Figure 3. Cultural Awareness and Extent of Global Involvement ( Hofstede: 1997) 
Globalization is a dynamic process which has big impacts on various cultures around the world. It can spread the western ideology and values across the world. For that reason, it is so clear that globalization is a challenge to Islamic cultural identity.

According to Nurullah (2008: 45), there are some reasons why globalization becomes the big threat for cultural identity. The first, globalization : (a) globalization promotes media so the hegemony of Western culture can be spread fast; (b) globalization can threaten the local culture to be replaced by Americanism, the secular one; (c) globalization challenges the collective Islamic ways of life, behavioral patterns, values, and principles. Moreover, he also said that there are so many scholars who argue that globalization can make cultural integration by breaking the cultural barriers and supporting the healthy cultural exchange. The arguments like this can make or spread American cultural hegemony globally. On the other hand, that cultural exchange makes the dominant American culture manipulated in the Muslim world, so it can replace Islamic culture. It can be said that globalization becomes big challenge for culture. From this explanation, it means that all Muslims around the world should be aware and careful with the consequences of globalization in culture and the power to keep the absolute Islamic cultural characters determined by God.

\section{The Existence of Kudus Islamic Local Culture to Prevent Radicalism in Globalization Era}

The presence of radical actions which developed recently is triggered by certain groups who have difficulty accepting pluralism in society. They do not like the diversity and force the creation of uniformity so that it arises such a radical action. Thus, it takes acculturation, which combines the differences that exist so that it becomes an entity in order to avoid violence.

The lost local identity that happens to the young generation recently becomes a reason of the appearance of radicalism. Losing local identity caused losing traditional values, thus the radicalism concept can be easily received. Many young generations had 
forgotten the ancestors's tradition values such as angsana diri (introspective), ang adohana ing perpadu (stay away from contention), and kanden wanci (get rid of the bad character). The Javanese culture contains the values of truth, virtue, values that can enrich the sense of justice, the ability of responsible, self-reliance, unity, ideals and manners. Actually those values come from the potential of Javanese culture that is local but the values are universal, so it can be used as the common values and can be used by anyone, anywhere and anytime.

The rise of radicalism in Indonesia is more worrying. Many terrorism cases were revealed in this last decade. Most of those radical actions involve the young generations. Concrete efforts need to be done soon by the government. One of them is make the revitalization of local culture.

In this case, the cultural approach has an important position. Therefore, it must also apply to education in schools. Students should be taught from an early age to solve some problem or conflicts by doing musyawarah (discussion), or doing a group games that engages many people (e.g. top, kite or hide and seek). Local values through the game can be a model of teaching in schools is quite effective in preventing radicalism and terrorism among students. Teachers can modify or manipulate the values of the local game has become to be a teaching material in order to strengthen the relationship between individuals and between groups.

While in Kudus, Sunan Kudus gives tolerant religious and cultural foundations. Sunan Kudus teachings of tolerance still exist until now where radicalism and religious fundamentalism are increasingly prevalent today. The way of his Dakwah also in line with the approach of Sunan Kalijaga propaganda that emphasizes local wisdom to appreciate the local culture. Some values of tolerance shown by Sunan Kudus to his followers is by banning cow slaughter to his followers. Not only prohibits for slaughter, the cattle was also placed in the courtyard of the mosque at the time. 
Another tolerance as well acculturation of Sunan Kudus can also be seen in the shower or padasan totaling eight which now functioned as a place of ablution (wudhu). Each shower is decorated with relief statues as an aesthetic ornament. Number eight on the shower adopts the Buddhist teachings that are Asta Sanghika Marga or Eight Main Street which becomes the guidance of society at that time in their lives.

The values of tolerance in religious life as contained in the teachings of Islam, has been well-adopted by our society that we can see in our local culture, such as place of worship, Kudus Mosque Minaret and Klenteng (Chinese temple) Holy Hok Bio Ling standing close together or side by side. In addition, the architecture of the Kudus Mosque Minaret is a combination of Muslim architecture with other religious architecture that is Islamic and Hindu architecture. Kudus Minaret architecture is not like the Middle East building but more similar to Candi Jago or similar with building temples in Bali.

The minaret is being used by Sunan Kudus as a place of adzan (call to prayer) and a place to beat the drum every time the arrival of Ramadan. Now, the minaret which is said to be the oldest minarets in Java becomes a landmark in Kudus regency.

\section{Conclusion}

Globalization is big threat for local wisdom, especially for Islamic Kudus local culture. One of those big threats is radicalism. Based on the finding and discussion, there are three conclusions. The first result of this study shows that Kudus regency is still very strong with their local wisdom. This is shown by the Islamic local cultures which are still preserved today, those are: Dandangan, Kupatan dan Syawalan, Bulusan, Kudus Mosque Minaret, Buka Luwur and Cow as Sacred Animal. Secondly, Globalization has big influence to Kudus Islamic local cultures. That is eroding those local cultures. Nevertheless, the third finding shows that Sunan Kudus teaching brings local wisdom of Kudus society could prevent the radicalism in this area. 


\section{REFERENCES}

Agung S., Leo. The Development of Local Wisdom-Based Social Science Learning Model With Bengawan Solo as the Learning Source. American International Journal of Social Science. Vol. 4, no. 4 August.

Asnawan, 2011. Islam dan Akulturasi Budaya Lokal di Indonesia. Jurnal Falasifa Vol 2, No.2 September.

Bivens-Tatum, W. 2016: Library Research Methods. Accessed on May 12th 2016. Retrieved from http://libguides.princeton. edu/c.php?g=84018\&p=664971.

Dulupçu, Murat Ali and Demirel, Onur. 2015. Globalization and Internationalization. Isparta: Education and Culture Programme

Ginsburg, F. 2002. Screen memories: Resignifying the Traditional in Indigenous Media. In F. Ginsburg, L. Abu-Lughod, and B.Larkin (Eds.), Media Worlds: Anthropology on a New Terrain (pp.39-57). Berkeley: University of California Press.

Hofstede, G. 1997. Cultures and Organizations: Software of the Mind. New York: McGraw Hill.

Indrahti, S. 2012. Kudus dan Islam: Nilai-Nilai Budaya Lokal dan Industri Wisata Ziarah. Retrieved from http://eprints. undip.ac.id/39024/

Khadziq. 2009. Islam dan Budaya Lokal: Belajar Memahami Realitas Agama dalam Masyarakat. Yogyakarta: Teras.

Mastuki, H. S. 2015. Islam, Budaya Indonesia, dan Posisi Kajian Islam di Perguruan Tinggi Islam. Khazanah: Jurnal Studi Islam Dan Humaniora, 12(1). Retrieved from http:// jurnal.iain-antasari.ac.id/index.php/khazanah/article/ view/298 
Nurullah, AS. 2008. Globalization as a Challenge to Islamic Cultural Identity. The International Journal of Interdisciplinary Social Sciences, Volume 3, Number 6

Purbasari, I., Fajrie, N., \& others. 2015. Revitalisasi Budaya Lokal Kota Kudus dalam Pengembangan Bahan Ajar di Sekolah Dasar. Refleksi Edukatika, 5(2). Retrieved from http:// jurnal.umk.ac.id/index.php/RE/article/view/445

Rachmawati, Murni dan Andy Mappajaya. 2012. Local Wisdom in Java's Architecture (Studied in Nature, Technology, and Humanity). Academic Research International. Vol.3, No. 1 July.

Said, N. 2016. Spiritual Enterprenership Warisan Sunan Kudus: Modal Budaya Pengembangan Ekonomi Syari'ah dalam Masyarakat Pesisir. Equilibrium: Jurnal Ekonomi Syariah, 2(2). Retrieved from http://journal.stainkudus.ac.id/ index.php/equilibrium/article/view/730

Smith, C. \& Ward, G. 2000. Indigenous Cultures in an Interconnected World. Vancouver: UBC Press.

Sumpena, D. 2014. Islam dan Budaya Lokal: Kajian terhadap Interelasi Islam dan Budaya Sunda. Ilmu Dakwah: Academic Journal for Homiletic Studies, 6(1), 101-120.

Suparjo, S. 2008. Islam dan Budaya: Strategi Kultural Walisongo dalam Membangun Masyarakat Muslim Indonesia. KOMUNIKA, 2(2), 178-193.

Widiana, N. 2015. Pergumulan Islam dengan Budaya Lokal: Studi Kasus Masyarakat Samin di Dusun Jepang Bojonegoro. Teologia, 26 (2). Retrieved from http://www.journal. walisongo.ac.id/index.php/teologia/article/view/428 